\title{
KONSEP PERTANIAN PULAU-PULAU KECIL BERBASIS GUGUS PULAU MENGHADAPI PERUBAHAN IKLIM GLOBAL DI PROVINSI MALUKU
}

\author{
Agustinus Kastanya \\ Program Studi Manajemen Hutan, Pascasarjana Universitas Pattimura Ambon \\ Jl. Dr.Ir. M. Latumeten, Kampus PGSD - Ambon 57131 \\ Penulis Korespondensi Email : aguskastanya@yahoo.co.id
}

Diterima : 3 Mei 2016

Disetujui : 2 Juli 2016

\section{Intisari}

Indonesia telah menetapkan Intended Nationally Determined Contributions (INDC) dan telah di submit ke UNFCCC, dengan upaya menurunkan gas emisi sebesar $29 \%$ dengan kemampuan sendiri dan $41 \%$ dengan bantuan pihak lain sampai tahun 2030. Hal ini dilakukan sebagai wujud dari Paris Agreement (COP 21) untuk mengendalikan gas emisi dunia sehingga kenaikan suhu bumi tidak mencapai $20 \mathrm{C}$. Maluku dengan karakteristik pulau-pulau kecil, DAS sempit dan pendek, memerlukan inovasi dalam konsep pembangunan. Basis pembangunan pada multi landscape pulau-pulau kecil yaitu gugus pulau, pulau, DAS, sesuai kondisi ekologi, ekonomi dan social budaya. Konsep pertanian pulau-pulau kecil berbasis multi lanskap dalam skema green economics, dikembangkan dalam 3 konsep dasar yaitu: (1) Kerangka konseptual; (2) Kerangka konsep makro;

(3) Kerangka konsep mikro. Wujud multi lanskap telah terintegrasi dalam DAS dan RTRWP/K yang dirancang dalam Unit pengelolaan terkecil sesuai hak tenurial/adat yang berlaku. Seluruh lanskap dikembangkan dengan sistem agroforestry sehingga terjadi kelestarian DAS, kelestarian pulau, kelestarian gugus pulau dan laut pulau. Dengan demikian konsep pertanian dapat memberikan tingkat produktivitas barang dan jasa dalam berbagai kebutuhan masyarakat dan lingkungan, serta tingkat mitigasi dan adaptasi terhadap perubahan iklim.

Kata Kunci : Ekonomi Hijau, Iklim global, Maluku, Manajemen Hutan, Pertanian pulau kecil

\begin{abstract}
Indonesia has already agreed to and submitted Intended Nationally Determined Contributions (INDC) to the UNFCCC, to reduce emission gases by $29 \%$ on its own and by $41 \%$ with outside help by 2030. This step follows the Paris Agreement (COP 21) to reduce world emission gases to prevent the earth warming by 20C. Maluku is characterized by small islands, narrow and short watersheds and needs an innovative approach to development. Multi landscape based development of small islands means using island clusters, watersheds, ecological conditions and socio-economic conditions. An agricultural concept for small islands based on multi landscape plans like green economics has been developed in 3 base concepts : (1) conceptual framework; (2) macro concept framework; (3) micro concept framework. The multi landscape format integrates water catchments and RTRWP/K which are organized into the smallest management units in accordance with indigenous rights. The complete landscape is managed using an agroforestry system for conservation of the watersheds, islands, cluster groups and seas. Thus, the agricultural concept can deliver productivity and services to meet the needs of the community and the environment as well as for mitigation of and adaptation to climate change.
\end{abstract}

Keywords : Agriculture small island, Forest managament, Global climate, Green economy, Mollucas 


\section{PENDAHULUAN}

Pemanasan dan perubahan iklim global telah menjadi keresahan dunia, karena dampaknya telah mengancam seluruh umat manusia dan biodiversitas di dunia, tanpa kecuali. Hal ini terjadi sebagai akibat perkembangan ekonomi dunia yang sangat ekploitatif tanpa memperhitungkan degradasi sumber daya alam dan lingkungan, deforestasi dan degradasi hutan. Indonesia sebagai Negara Kepulauan yang sangat rentan terhadap perubahan iklim global telah menetapkan komitmen untuk menurunkan gas emisi (Gas Rumah Kaca/GRK) sebesar $26 \%$ dengan kemampuan sendiri, danakan ditingkatkan menjadi $41 \%$ dengan bantuan lain, dari business as usual (BAU) pada tahun 2020 bahkan ditingkatkan menjadi $29 \%$ dengan kemampuan sendiri pada tahun 2030. Penurunan GRK dalam konsep ekonomi hijau harus dilaksanakan dalam semua sector pembanguan. Khusus di sector penggunaan lahan sebagai hasil keputusan UNFCCC tentang REDD+ (Reducing Emission from Deforestation and degradation+) yang saat ini telah dirancang dan dikembangkan untuk menjadi arus utama dalam konsep pembangunan Indonesia (Kastanya 2014 dan Aninomus, 2016).

Provinsi Maluku dengan jumlah pulau kecil 1.340 pulau. Laut yang luas (92\%) dan daratan yang sempit (8\%) memiliki Daerah Aliran Sungai (DAS) yang sempit dan pendek, membentuk ekosistem spesifik, saling berhubungan dan mempengaruhi satu dengan lainnya, sumberdaya hutan dan lautan memiliki biodiversitas yang kaya dengan sifat endemik, memiliki daya rentan yang tinggi, apabila mengalami gangguan. Terganggunya ekosistem di daratan akan langsung mempengaruhi ekosistem pesisir dan lautan. Kondisi sosial ekonomi masyarakat dengan kearifan lokal, termasuk hak masyarakat adat yang sangat beragam sesuai kondisi lingkungan spesifik, relasi biodiversitas dan manusia dengan lingkungannya membentuk ekosistem pulau-pulau kecil yang sangat spesifik dan unik.

Sayangnya kondisi ini tidak diperhatikan dalam merancang konsep pembangunan.

Pembangunan yang berlangsung selama ini sangat sektoral, terutama sektor pertanian dalam arti luas, konversi lahan dan ekosistem spesifik (sagu, mangrove) terjadi secara besar-besaran untuk sektor pertanian, peternakan, perikanan, pemukiman, infrastruktur, pertambangan diikuti dengan pengelolaan hutan yang merusak. Kondisi demikian akan menghadapi ancaman dengan tantangan perubahan iklim yang sangat berbahaya (Kastanya, 2002; 2012; 2013; 2014 dan Aninomous, 2016).

Kondisi ekosistem pulau kecil yang telah dirumuskan dalam Rencana Tata Ruang Provinsi atau Kabupaten/Kota (RTRWP/K) dengan tantangan perubahan iklim memerlukan penyesuaian dan perubahan secara menyeluruh untuk seluruh sektor pembangunan. Integrasi pembangunan berbasis ilmu penegtahuan dan teknologi sesuai kondisi ekologi, sosial dan ekonimi pulau kecil dengan berlandaskan pada ekonomi hijau (green economics) merupakan kebutuhan yang sangat mendesak. Khusus untuk sektor penggunaan lahan (pertanian/perkebunan, kehutanan, peternakan dan perikanan) pada pulaupulau kecil memerlukan suatu konsep yang terintegrasi yang dirumuskan dalam "Konsep Pertanian Pulau-Pulau Kecil" berbasis ekonomi hijau (green economics).

\section{Perubahan Iklim, Tantangan dan Peluang}

Perubahan iklim diakibatkan oleh akumulasi emisi gas rumah kaca (GRK), yang merupakan gas karbon dioksida $\left(\mathrm{CO}_{2}\right)$, metana $\left(\mathrm{NH}_{4}\right)$, dinitrogen oksida $\left(\mathrm{N}_{2} \mathrm{O}\right)$, hidrofluorokarbon (HFC), perfluorokarbon (PFC) dan sulphur heksafluorida $\left(\mathrm{SF}_{6}\right)$. GRK tersebut ada fungsi alami yaitu untuk meredam perbedaan temperature ekstrim dari siang dan malam, dan dapat menahan sebagaian radiasi ke angkasa luar pada malam hari dan menga-kibatkan akumulasi panas sehingga rata-rata temperature di bumi menjadi lebih hangat. Pemanasan global ini adalah fenomena siklus alami, dan telah terjadi selama puluhan ribu tahun.Siklus alami berubah akibat tingginya konsentrasi GRK merupakan akumulasi emisi GRK antropogenik, yaitu emisi yang berasal dari kegiatan manusia, utamanya akibat pembakaran bahan bakar berbasis fosil.Dimulai dari revolusi industry abad ke 19 di Eropa, proses pembangunan di seluruh dunia memanfaatkan sumber energy berbasis fosil. Selain energi berbasis fosil, sumber emisi cukup besar adalah perubahan dan alih fungsi lahan. Lahan yang tertutup oleh tumbuhan dan berbentuk hutan memiliki kemampuan untuk menyerap dan mengubah GRK, khusus $\mathrm{CO}_{2}$ menjadi zat pati dan oksigen. Alih fungsi lahan 
dari hutan menjadi lahan pertanian, pemukiman, perkembangan infrastruktur serta manufaktur dan lain-lain menghilangkan kemampuan bumi untuk melakukan fungsi penyerapan. Masalah digandakan oleh kecepatan perkembangan dan pengeluaran emisi disemua bagian di dunia.

Akibat pemanasan global, atmosfir yang terdiri dari gas sangat mudah terpengaruh. Hal ini sejalan dengan hukum gas yang sangat dipengaruhi oleh temperature. Perubahan tempe-rature menyebabkan perubahan tekanan volume gas yang relativ tetap, maka terjadilah peru-bahan arah dan kecepatan angin, selain juga kelembaban udara dan tutupan awan yang mengakibatkan pergeseran waktu dan karakteristik musim. Gangguan tersebut mengakibatkan perubahan iklim yang dialami dan dirasakan oleh seluruh dunia (DNPI. 2013)

Dampak perubahan iklim meliputi dampak primer, dampak sekunder dan dampak turunan. Salah satu dampak turunan adalah pelelehan lapisan es dipegunungan tinggi, sungai es dan gunung es di lautan kutub utara dan kutub selatan yang mendampak diantaranya kepada peningkatan muka air laut. Masalah ini ditambah dengan pemuaian volume air laut yang karena panas meningkat. Berdasarkan pengematan, peningkatan muka air laut akan terjadi sekitar 2 kali hingga tahun 2100 dan bahkan dapat meningkat hingga 6 kali jika emisi GRK tidak ditangani.

Es mencair terdiri dari air laut yang masuk ke badan laut yang merupakan air asin. Akibatnya adalah pengenceran air asin yang hangat dari daerah tropis.akibatnya suhu dan temperature air dipermukaan pun menjadi dingin dan ini berakibat pada masa udara diatasnya. Terjadinya pencampuran air maka dinamika fisik air laut yang selama ini terjadi akibat perbedaan salinitas air akan mengalami gangguan sehingga sabuk air laut (Great Ocean Conveyor Belt) akan melambat, demikian pula dengan sirkulasi air laut dunia. Hal ini berdampak terhadap dinamika fisik lapisan udara di atas muka bumi . Temperature di belahan bumi utara akan semakin dingin serta musim dingin akan semakin panjang dan ekstrim sehingga akan mengganggu kondisi atmosfir di seluruh muka bumi. Berdasarkan penelitian yang dilakukan, diperkirakan belahan bumi utara akan memiliki temperature rata-rata sekitar 5 derajat Celsius lebih dingin dari saat ini (DNPI 2013 dan Aninomous 2016).

Pada daerah tropis, temperatur akan semakin meningkat, baik di atas permukaan air maupun dibawah laut. Berdasarkan penelitian, peningkatan dari temperatur air laut di daerah tropis memberi dampak negativ pemutihan karang, atau coral bleaching, terhadap karangkarang di laut yang berdampak terhadap populasi flora dan fauna di bawah laut. Dampak dari peningkatan temperatur di atas permukaan air laut dapat terlihat dari kekeringan yang semakin sering dialami dan semakin panjang lamanya.

Sebagaimana dilihat, semua dampak yang dialami secara fisik akan berdampak terhadap pola hidup sehari-hari. Perubahan akan berdampak terhadap pola migrasi populasi, kepada pengurangan stok pangan karena cuaca ekstrim yang mem-pengaruhi penghasilan nelayan dan petani. Pada kondisi ekstrim, perubahan iklim dapat menjadi dasar dari konflik dan perang dikarenakan kekurangan sumberdaya alami, lahan, bahan bakar dan pangan.

Perubahan iklim menjadi tantangan di semua sektor dan semua bagian dunia. Karena masalah-masalah yang kompleks dan rumit dari dampak perubahan iklim, sangat diperlukan perhatian semua pihak. Banyak peluang yang telah tercipta melalui skema penanganan melalui perundingan internasional antara negara maju dan negara sedang berkembang, negara sedang berkembang dapat memanfaatkan peluang dari skema pembiayaan internasional dan perdagangan karbon walaupun masih dalam tahap perundingan. Munculnya gagasan ekonomi hijau (Green Economy) oleh masyarakat internasional sebagai paradigma ekonomi baru, karena ketidak puasan banyak stakeholder dengan paradigma 
ekonomi konvensional yang bersifat ekploitatif, yang dijalankan selama ini oleh pihak pemerintah, ahli ekonomi dan pihak lainnya, yang lebih berorientasi pada keuntungan berupa uang atau mengejar pertumbuhan ekonomi dari pada mempertimbangkan dampak negatip terhadap lingkungan, kemiskinan umat manusia, pemanasan dan perubahan iklim global. Pada dekade terakhir ini, sudah terjadi berbagai krisiss termasuk krisis iklim, kehilangan biodiversitas, krisis lingkungan, kenaikan harga bahan bakar, kri krisis energi, kekurangan bahan pangan, air bersih, dan krisis sistem finansial global. Semua ini merupakan tantangan besar dalam perkembangan dunia saat ini dan ke depan, terutama mengantisipasi pertambahan pen-duduk, yang diprediksikan akan mencapai 9 milyard orang, pada tahun 2050 ( UNEP, 2011; DNPI, 2013; Kastanya, 2014; Aninomous, 2015).

Ekonomi hijau (Green economy) adalah sistem ekonomi yang dapat menciptakan kesejahteraan umat manusia dan terjadi pemerataan sosial, untuk seluruh lapisan masya-rakat dan secara signifikan mengurangi risiko terhadap lingkungan dan kelangkaan ekologi. Atau dengan sedehana dapat dikatakan bahwa Green Economy adalah pembangunan yang menghasil-kan karbon rendah, pemakaian sumber daya secara efisien dan terjadi pemera-taan sosial untuk seluruh lapisan masyarakat (UNEP, 2011). Karena itu diperlukan pengelolaan yang terin-tegrasi untuk meng-hasilkan kesejahteraan bagi masyarakat, tetapi juga menjamin ketersediaan sumberdaya alam bagi generasi yang akan datang. Dengan demikian baik sektor yang memiliki modal alam atau sektor primer seperti pertanian, kehutanan dan perikanan, maupun sector ekonomi yang bersifat sekunder atau yang disebut "built capital" seperti transportasi, energy, perindustrian dan lain-lain dapat dikembangkan untuk penghematan energi, pengembangan dan penggunaan energi terbaru-kan, dan penghematan sumberdaya menuju pertumbuhan ekonomi dan penciptaan lapangan kerja yang menghasilkan dampak positif demi terciptanya keadilan sosial bagi seluruh masya-rakat.

Banyak solusi yang dapat dilaksanakan secara mendasar, mulai dari perubahan paradigma pembangunan ekonomi menuju ekonomi hijau (green economics), mengintegrasikan skema perubahan iklim dengan konsep pembangunan berkelanjutan. Khusus untuk pulau-pulau kecil di Maluku, merumuskan kembali konsep pertanian pulaupulau kecil, dengan mempertimbangkan ekologi, ekonomi dan sosial masyarakat, mengintegrasikan skema perubahan iklim terutama skema REDD+, pembaharuan dalam system pendidikan pertanian yang dapat mendukung konsep pembangunan pertanian pulau-pulau kecil, sebagai upaya mitigasi dan adaptasi untuk menjamin pembangunan emisi rendah, memanfaatkan sumberdaya alam secara lestari, memperhatikan hak-hak masyarakat dgn kearifan local, menjamin kesejahteraan masyarakat dengan pemerataan sosial bagi seluruh masyarakat.

\section{ANALISIS DAN PEMBAHASAN}

\section{Konsep Pertanian Pulau - pulau Kecil (Berbasis Kewilayahaan)}

Provinsi Maluku dimekarkan menjadi Provinsi Maluku dan Maluku Utara. Provinsi Maluku memiliki karakter yang spesifik, terdiri dari 1.340 buah pulau, luas wilayah $712.479,65$ $\mathrm{Km} 2$, luas daratan $54.185 \mathrm{Km} 2$, luas perairan $658.294,69 \mathrm{Km} 2$, dengan panjang garis pantai $10.662 \mathrm{Km}$. Kondisi demikian memiliki karekter ekologi dengan luas Daerah Aliran Sungai (DAS) yang sempit, kondisi biogeofisik, sosial, ekonomi masyarakat bervariasi, daerah pantai dan lautan yang luas yang mempengaruhi proses HIDROOROLOGI, ekosistem terdekat berkaitan dan saling mempengaruhi, ketersediaan air bersih dan air tanah terbatas, dipengaruhi letusan gunung berapi, gempa bumi, tanah longsor dan angin puyuh/badai tropis, dipengaruhi langsung oleh iklim maritim, memiliki populasi spesies endemik yang tinggi, terisolasi, kebanyakan masyarakat miskin, terikat pada budaya/adat, ekonomi lokal yang tidak berkembang men-dorong migrasi penduduk ke kota dan terjadi kelangkaan sumberdaya manusia berkualitas di pedesaan (Monk, dkk. 1997; Kastanya 2002; 
2014). kelangkaan sumberdaya manusia berkualitas di pedesaan (Monk, dkk, 1997; Kastanya 2002; 2014).

Karakteristik tersebut sangat rentan terhadap kerusakan lingkungan terutama pemanasan dan perubahan iklim global, dan dampaknya sebagaimana di jelaskan di atas. Dampak tersebut sudah terjadi selama beberapa dekade ini yang dari tahun ke tahun menunjukkan trend yang meningkat tanpa dapat dikendalikan. Berdasarkan kondisi dan karakterisitik demikian telah ditetapkan struktur tata ruang wilayah provinsi dan kabupaten/kota (RTRWP/K) sebagai konsep pembangunan wilayah, namun belum terintegrasi dengan DAS dan pembangunan sektoral. Konsep pertanian pulau-pulau kecil dikem-bangkan secara terintegrasi yaitu integrasi RTRWP/K dengan DAS sebagai unit ekologi yang dapat mengukur proses hidrorologis diikuti dengan rencana pembangunan sektoral dan kondisi sosialekonomi masyarakat. Dengan demikian rencana seluruh sektor pembangunan terutama pertanian/perkebunan, kehutaan, peternakan dan perikanan telah terpadu dalam konsep pembangunan wilayah yang terpusat di dalam DAS. Selama ini dokumen rencana pembangunan wilayah (RTRWP/K dan DAS) hanya dibuat sebagai persyaratan administratif dan tuntutan per-undang-undangan. Karena itu terjadi kerusakan lingkungan dan kemiskinan, yang menyebabkan pemanasan dan perubahan iklim global. Konsep Pertanian Pulau-Pulau Kecil yang lestari/berkelanjutan, yang berbasis pada konsep ekonomi hijau (Kastanya, 2002; 2010) dapat dilihat pada Gambar 1.

\section{Kerangka Konseptual}

Kerangka konseptual yaitu melakukan pembaharuan konsep ekonomi konvensional yang mengejar pertumbuhan dan bersifat eksploitatif menuju ekonomi hijau (green economics) yang dibangun atas dasar keseimbangan antara teori ekologi, ekonomi dan sosial untuk mendukung pembangunan lestari atau berkelanjutan dengan indikator dan sasaran yang harus dicapai yaitu: (1) reduksi emisi; (2) cadangan karbon meningkat; (3) keragaman hayati dan jasa lingkungan terpelihara; (4) pertumbuhan ekonomi.

Hal yang penting ekosistem asli terpelihara/lestari (Sagu, mangrove, habitat satwa, padang lamun, terumbu karang); sumberdaya lahan/hutan mendukung kelestarian produksi (pangan, energy terbarukan, Karbon rendah, menurunkan GRK, jasa ekosistem, Hasil hutan kayu, HHBK), konservasi biodiversitas (konservasi biologi, keragaman hayati, konser-vasi spesies-populasi-komunitas, penyim-panan karbon); pertumbuhan ekonomi lestari berbasis masyarakat (social forestry, agro-forestri, berorientasi pada TENH, pertumbuhan ekonomi, lingkungan terjamin), sosial-budaya masyarakat (hak ulayat/adat, kearifan lokal, masyarakat sejahtera, pendidikan berbasis masyarakat /community collages, pemerataan sosial), pemerataan sosial), mitigasi dan adaptasi terhadap bencana dan perubahan iklim, insti-tusi/kelembagaan (perundang-undangan, Perda, desentralistik-otonomi, kelembagaan masyara-kat, pemerintah daerah yang kuat). Kerangka konseptual dengan seluruh indikator menjadi landasan dalam merumuskan kerangka konsep makro dan mikro.

\section{Kerangka Konsep Makro}

Mengintegrasikan seluruh rencana pembangunan sektoral dalam pembangunan wilayah. Khusus untuk sector penggunaan lahan yaitu sektor kehutanan, pertanian, peternakan dan perikanan, sedangkan rencana pembangunan wilayah adalah Rencana Tata Ruang Wilayah Provinsi/Kabupaten (RTRWP/K, berbasis gugus pulau dan laut pulau) dan Daerah Aliran Sungai (DAS) pulau-pulau kecil. Perlu dikembangkan konsep DAS pulau-pulau kecil pada 1.340 pulau. Untuk pulau kecil, satu pulau satu DAS. BPDAS Maluku telah mengembangkan 152 DAS di Provinsi kepulauan Maluku. Hal ini perlu ditinjau kembali sesuai kondisi wilayah Maluku. Seharusnya untuk 1.340 pulau, harus memiliki DAS yang lebih dari jumlah pulau, karena untuk pulau Seram, pulau Buru, pulau Ambon dan pulau lainnya memiliki DAS lebih dari satu.

Hal ini perlu diidentifikasi bentuk dan 


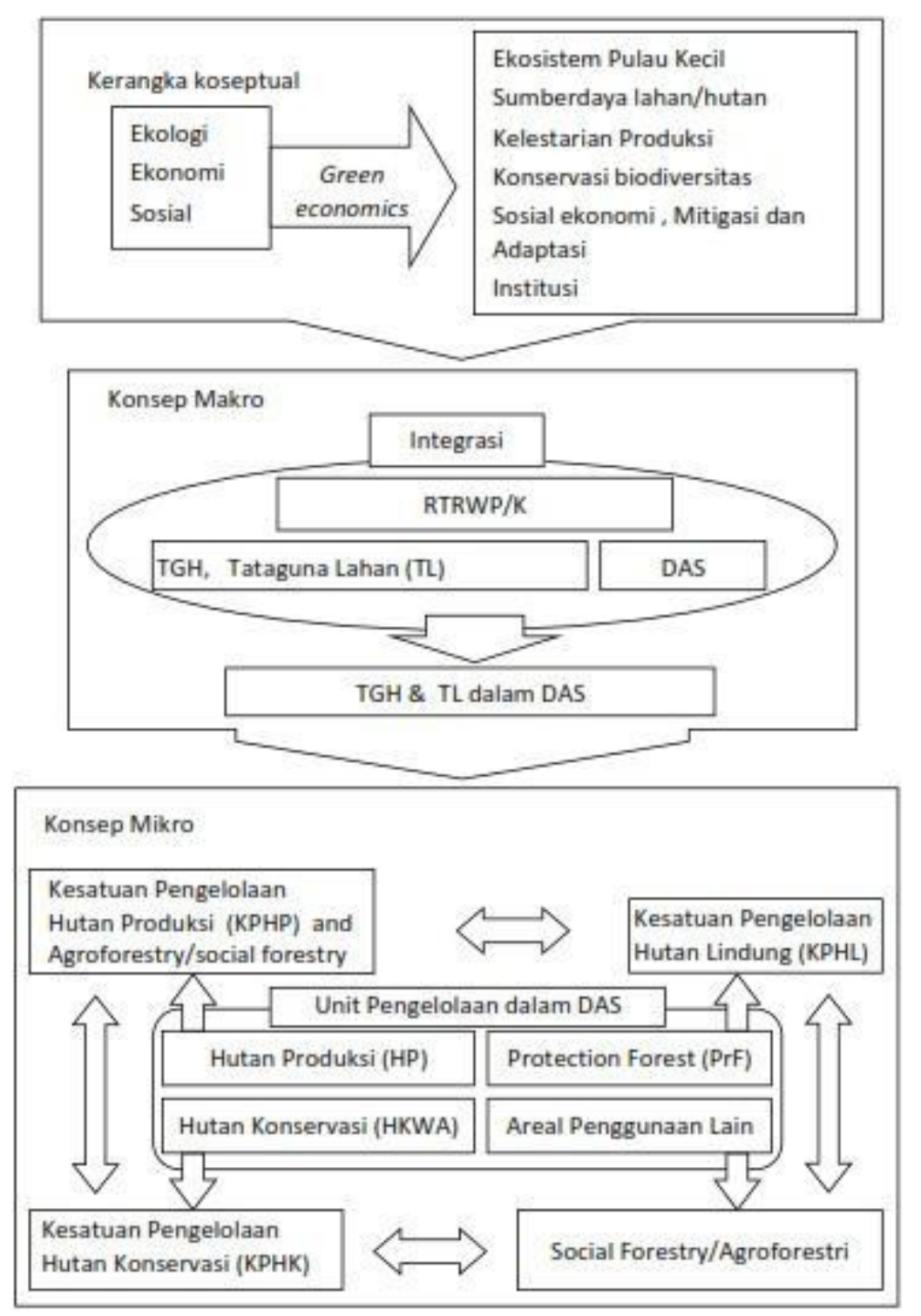

Gambar 1 . Diagram Konsep Pertanian Pulau-Pulau Kecil

karakteristik DAS nya, sesuai kondisi biogeofisik, sosial dan ekonomi masyarakat yang ada di dalam DAS tersebut. Inilah yang membedakan sifat dan karakteristik pulau-pulau kecil dengan wilayah kontinental. Dengan demikian seluruh rencana sektoral diintegrasikan dalam RTRWP/K dan DAS. Untuk sektor kehutanan TGH di integrasikan dalam DAS dan RTRWP. Indikator keberhasilan pembangunan harus diukur secera ekologi, ekonomi dan sosial dalam unit DAS yang berada dalam pulau dan gugus pulau. Konsep makro kemudian dijabarkan dalam konsep mikro berupa unit-unit pengelolaan, yang harus dikelola secara lestari.

\section{Kerangka Konsep Mikro}

Seluruh rencana sektoral yang telah terintegrasi dalam DAS dan RTRWP/K yang dirancang dalam Unit pengelolaan terkecil yang dikelola secara terintegrasi dan lestari/berkelanjutan, sehingga dapat mencapai kelestarian DAS dan kelestarian gugus pulau dan laut pulau yang berarti dapat mencapai kelestarian seluruh kawasan pulau-pulau kecil di Maluku. Unit pengelolaan terkecil seperti terlihat pada Gambar 1, terdiri dari:

1. Kesatuan Pengelolaan Hutan Produksi (KPHP/social forestry)

2. Kesatuan Pengelolaan Hutan Lindung (KPHL/social forestry).

3. Kesatuan Pengelolaan Hutan Konservasi 
(KPHK/social forestry)

4. Kesatuan Pengelolaan

Agroforestri (KPA) terdiri dari:

1. Agrosilviculture

2. Agrosilvopasture

3. Permakultur

4. Agrosilvopasturefisheries

Seluruh sektor pembangunan dan bidang ilmu yang meliputi penggunanan lahan telah terintegrasi dan tidak dikembangkan secara sektoral tetapi dalam model pengelolaan Social forestry dan agroforestri. Pengembangan model social forestry dalam KPH dengan mengintegrasikan partisipasi masyarakat di dalamnya miliputi model Hutan Kemasyarakatan, Hutan Rakyat, Hutan Desa yang tidak hanya menghasilkan kayu tetapi juga hasil hutan bukan kayu (HHBK) atau Total Ekonomi Nilai Hutan termasuk pangan, energy terbarukan, ekowisata, jasa hutan dan lain-lain. Sedangkan pengembangan pada Areal Penggunaan lain (APL) meliputi pertanian/perkebunan, peternakan, perikanan, pemukiman, infrastruktur dan lainlain dapat dikembangkan dengan model Agroforestri.

Keberhasilan implementasi konsep yang digambarkan di atas, apabila didukung oleh sumberdaya manusia yang berkualitas yaitu tenaga professional, terampil, siap kerja dan soft skill tinggi. Karena itu perlu dibangun community collage atau akademi komunitas (program sertifikat dan diploma), untuk mendukung unitunit pangelolaan lestari sesuai kerangka konsep mikro. Dasar-dasar pendidikan agroforestri perlu dikembangkan untuk pendidikan pertanian,

peternakan, perikanan untuk menunjang pembangunan pertanian pulau-pulau kecil.

Sehubungan dengan ruang lingkup tersebut maka bidang agroforestri memainkan peranan yang sangat penting untuk menciptakan struktur tegakan yang hampir menyerupai hutan alam, yang secara ekologi, ekonomi dan sosial dapat mencapai hubungan yang serasi, dalam prinsip-prinsp ekonomi hijau. Pengembangan agroforestri dapat menekan laju defo-restasi dan degradasi hutan, rehabilitasi dan restorasi kawasan yang rusak, peningkatan kelestarian keanekaragaman hayati, menyimpan/ meningkatakan stock carbon dan menghasilkan produk yang multiguna bagi peningkatan kesejahteraan masyarakat lokal.

\section{PENGEMBANGAN KONSEP PERTANIAN PULAU-PULAU KECIL DI PROVINSI MALUKU}

Pengembangan konsep pertanian pulaupulau kecil seperti dijelaskan di atas, diimplementasikan di Propinsi Maluku seperti tergambar pada gambar 2.dimana multi lansekap yaitu 12 gugus pulau, 1.340 pulau dan lebih dari 1. 340 DAS, yang sudah terintegrasi. Seluruh data geobiofisik, sosial budaya-ekonomi dan rencana seluruh sektor terdistribusi dalam DAS sebagai unit pengelolaan lestari. Secara operasional data biogeofisik (peta vegetasi/penutupan lahan, biodiversitas, geologi, tanah, unit lahan, curah hujan dan data lainnya yang tersedia). Data sosial budaya menyangkut pendidikan, kualitas hidup, kearifan lokal, hak tenurial/ulayat/hak masyarakat hukum adat, penguasaan teknologi dan perkembangan ekonomi masyarakat. Sedangkan rencana sektoral adalah rencana tetaguna lahan (landuse) sektor kehutanan, pertanian, peternakan, perikanan, pemukiman, infratruktur dan lainnya (Kastanya, 2012). Khusus untuk sosial budaya telah di kembangkan "Panduan pelibatan masyarakat lokal" dalam implementasi REDD+ di Indonesia Timur yang dapat dipakai untuk integrasi dalam konsep tersebut (Handoyo, Dkk. 2014).

Rencana Tata Guna Hutan (landuse kehutanan) yaitu luas kawasan hutan di Provinsi Maluku 4.390.640 ha, terdiri dari Hutan Konservasi 406.569 ha $(9,26 \%)$, Hutan Lindung (HL) 618.744 ha $(14,09 \%)$, Hutan Produksi Terbatas (HPT) 926.533 ha $(21,10 \%)$, Hutan Produksi (HP) 667.513 ha $(15,20 \%)$, dan Hutan Produksi yang dapat dikonversi (HPK) 1.771.281 ha $(40,34 \%)$. Sedangkan areal penggunaan lain (APL) sebesar 755.154 ha $(18,97 \%)$. Seluruh fungsi hutan telah terdistribusi dalam DAS. Untuk fungsi hutan konservasi akan dikem-bangkan unit pengelolaan manjadi KPHK, fungsi hutan Lindung dan Produksi, kecuali HPK dikembangkan KPHL dan KPHP. 


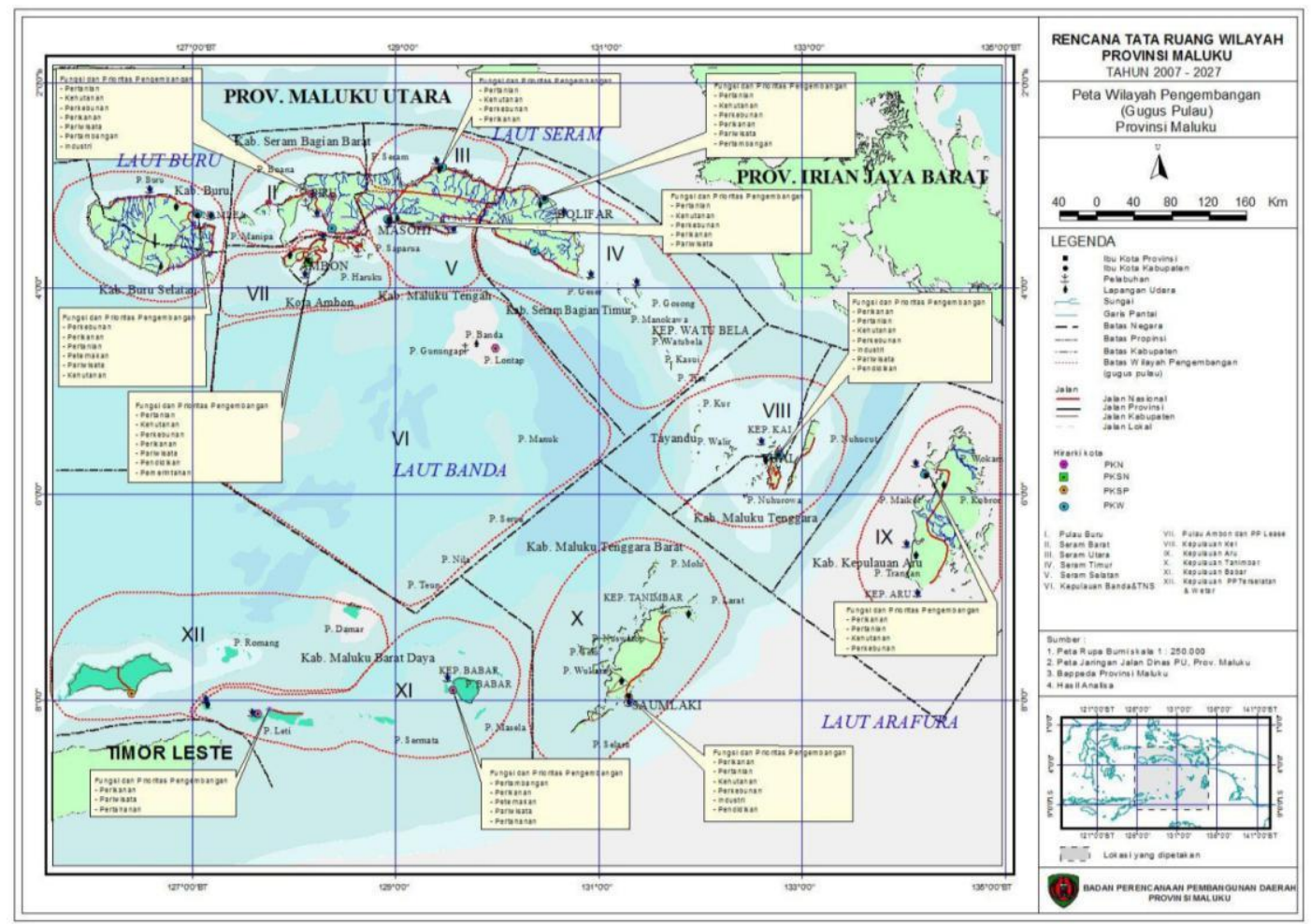

Gambar 2 . Peta WilayahPengembangan (Gugus Pulau) Provinsi Maluku

Kesatuan Pengelolaan Hutan (KPH) adalah wilayah pengelolaan hutan sesuai fungsi pokok dan peruntukannya, yang dapat dikelola secara efisien dan lestari. Seluruh kawasan hutan Provinsi Maluku terbagi dalam KPH yang menjadi bagian dari sistem pengurusan hutan nasional, pemerintah provinsi dan kabupaten/kota. KPH (KPHL dan KPHP) yang mempunyai lebih dari satu fungsi pokok (Ptoduksi atau Lindung), penetapannya berdasar-kan fungsi yang luasannya dominan. Pembagian wilayah kelola KPH berdasarkan kajian kelayakan ekologis, kepastian wilayah kelola, kelayakan kelembagaan dan pemanfaatan hutan diperoleh 22 $\mathrm{KPH}$, terdiri dari $17 \mathrm{KPHP}$ dan $5 \mathrm{KPHL}$ dengan luas seluruhnya 2.207.864 Ha.

Hal ini berarti masih tersisa dari HL dan Hutan Produksi (HP, HPT) seluas 4.926 Ha yang belum masuk dalam KPH yang terpencar tidak terkonsentrasi . Sedangkan fungsi hutan konservasi seluas 406.569 ha $(9,26 \%)$, yang sementara dirancang menjadi KPHK, meru-pakan kewenangan pemerintah pusat. Permasala-han yang masih dihadapi saat ini adalah luas hutan produksi konversi yang sangat luas 1.771.281 ha $(40,34 \%)$ yang dicadangkan untuk dikonversi merupakan dikonversi merupakan potensi deforestasi dan degradasi yang sangat besar yang akan merusak ekosistem hutan pulau-pulau kecil dan memberi dampak peningkatan gas emisi.

Hal ini harus mendapat perhatian khusus oleh pemerintah daerah untuk melakukan revisi RTRWP dan TGH. Areal tersebut Sebaiknya tetap menjadi hutan dan dirancang menjadi $\mathrm{KPH}$ dengan mempertimbangkan kawasan yang dapat dikonversi untuk sector lain, apabila sangat diperlukan dan mendesak.

Areal Penggunaan Lain (APL) sebesar 755.154 ha $(18,97 \%)$ adalah areal yang sudah dialokasikan untuk pertanian, peternakan, perikanan, pemukiman, perkantoran, infrastruktur dan lain-lain. Akibat dari pembang-unan sektoral maka masing-masik sektor mengembangkan sektornya tanpa berintegrasi dengan lainnya, cenderung mengembangkan usaha dengan pola monokultur,sering meng-konversi ekosistem asli seperti mangrove dan sagu karena pertimbangan yang sempit. Diharapkan pengembangan sektor ini berbasis pada konsep agroforestri dengan pendekatan lanskap sehingga dapat terbangun secara terintegrasi yang dapat menjamin keutuhan ekosistem dan lingkungan dan dapat menghasilkan produk dan jasa lingkungan yang optimal. 


\section{KESIMPULAN}

Pembaharuan kebijakan secara nasional sudah lebih terarah dan menjadikan skema perubahan iklim (metigasi dan adaptasi) sebagai arus utama dalam pembangunan nasional dan daerah.

\section{DAFTAR PUSTAKA}

Aninomous. 2015a. SIDIK. Sistem Informasi Data Indeks Kerentanan. Direktorat Adaptasi Perubahan Iklim Direktorat Jenderal Pengendalian Perubahan Iklim Kementerian Lingkungan Hidup Dan Kehutanan Jakarta. , 2015b. National Forest Reference Emission Level For Deforestation And Forest Degradation. In the Context of Decision 1/CP.16 para 70 UNFCCC (Encourages developing country Parties to contribute to mitigation actions in the forest sector). Directorate General of Climate Change. Ministry of Environment and

Forestry Submission by Indonesia. , 2016. Perubahan Iklim, Perjanjian Paris, Dan Nationally Determined Contribution. Direktorat Jenderal Pengendalian Perubahan Iklim. Kemen-terian Lingkungan Hidup dan Kehutanan. Jakarta.

BAPENAS. 2011. Pedoman Penyusunan Rencana Aksi Daerah Penurunan Emisi

Gas Rumah Kaca, tahun 2011. Kementerian Perencanaan Pembangunan Nasional/Badan Perencanaan Pembang-unan Nasional.

BAPENAS. 2012. Pedoman Pelaksanaan Rencana Aksi Penurunan Emisi Gas Rumah Kaca, 2011. Kementerian Perencanaan Pembangunan Nasional/ Badan Perencanaan Pembangunan Nasional.

Dewan Nasional Perubahan Iklim (DNPI), 2013. Perubahan Iklim Dan Tantangan Peradaban Bangsa. Diterbitkan Dalam Rangka Ulang
Tahun Ke-5 DNPI, 4 Juli 2013.

Dinas Kehutanan Provinsi Maluku. 2010. Buku Rencana Tindak (Action Plan) Pembangunan KPH Provinsi Maluku.

Food and Agriculture Organization of the United

Nations (FAO). 2010. Global Forest Resources Assessment Country Reports (Brunei Darussalam, Cambodia, Indonesia, Lao PDR, Malaysia, Myanmar, Philippines, Singapore, Thailand, and Vietnam).

Food and Agriculture Organization of the United Nations (FAO) . 1992 . Community Forestry: Ten Years in Review. Rome. u5610e04.htm (accessed on 10 th November 2010).

Hakim dkk. (2010). Social Forestry. Menuju Restorasi Pembangunan Kehutanan Berkelanjutan. Kementerian Kehutanan.

Badan Penelitian Dan Pengembangan . Pusat Penelitian Dan Pengembangan Perubahan Iklim Dan Kebijakan. Desember 2010

Handoyo, dkk. 2014. Panduan Pelibatan Masyarakat Lokal dalm Implementasi REDD+. Di Indonesia Timur. Badan Penelitian Dan Pengembangan Kehutanan. Pusat Penelitian Dan Pengembangan Perubahan Iklim Dan Kebijakan.

Kastanya, A. 2002. Pengelolaan Hutan Produksi Lestari Berbasis Gugus Pulau di Maluku.

Disertasi. Tidak Diterbitkan. Universitas Gadjah Mada. Yogyakarta , 2011. Penglolaan Hutan Tropis Pulau-

Pulau Kecil dalam Menghasilkan Bioenergi Energi dan Penyimpanan Karbon. Berkala Penelitian Hayati (Journal Of Biological researches). Special Topics in Zoology, Microbiology, A n d Envirenment . 19: 94 99. Jurnal Terakreditasi B, Edisi Khusus, No. 7F Tahun 2011. (ISSN: 0852-6834) 2012. A Community and Ecosystembased Sustainable Forest Management Model for Small Islands in Maluku. Journal of Agriciultural Science and Technology B Volume 2, Number 4, April 2012 (serial Number 12). Hal. 418. (ISSN 2161-6264) 
, 2013. Konsep Pertanian Pulau-Pulau

Kecil Berbasis Gugus Pulau Menghadapi Perubahan Iklim Global Di Provinsi Maluku. Makala disampaikan Dalam Seminar Nasional Dalam Rangka Dies Natalis ke-50 tahun. Program Studi Manajemen Hutan, PPS UNPATTI.

, 2014. Rencana Pengelolaan Multi LanskapPulau-Pulau Kecil Berbasis Ekonomi Hijau (Green Economics) Di Kepulauan Maluku. Pidato Pengukuhan. G u r u B e s a r Te $\mathrm{t}$ a $\mathrm{p} \mathrm{B}$ i d a $\mathrm{n}$ g I $1 \mathrm{~m}$ u Perencanaan dan Ekonomi Sumber Daya Hutan Jurusan Kehutanan Fakultas Pertanian Universitas Pattimura Ambon.

Monk, K. A., de Fretes, Y. and G. R. Lilley. 1997. The Ecology of Nusa Tenggara and Maluku. The Ecology Indonesia Series, Volume V. Oxford University Press

RECOFTC (2010). The Role of Social Forestry in Climat Change Mitigation and Adaptation in the ASEAN Region. Assessment 2010

RECOFTC \& The Learning Institute. 2010. Capacity Building Needs Assessment; Country Profile of Community Forestry and Community Protected Area Manage-ment in Cambodia (Working Draft).25 August 2010.

Siscawati, M, dan Zakaria, R.Y. 2010. Capacity Building Needs Assessment for Community Forestry in Indonesia. RECOFTC, Bogor. 